\title{
COMPARATIVE STUDIES IN
}

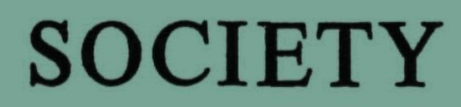

AND

\section{HISTORY}

An International Quarterly

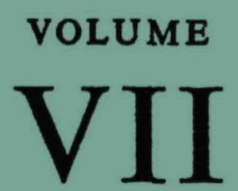

NUMBER 2 - JANUARY 1965

MOUTON \& CO - PUBLISHERS

THE HAGUB - NETHBRLANDS 


\section{CONTENTS}

Debate: Accounting for Change

KenNeTh Keniston, Accounting for Change . . . . . . $\quad$. 117

Robert Jay Lifton, On Psychology and History: Further Comment 127

Debate: Secularism East and West

Marc Galanter, Secularism, East and West (A review of Donald

Eugene Smith, India as a Secular State, Princeton, 1963) . . 133

JoHn T. Flint, India as a Secularizing State (A review of the same). 160

Donald E. SMITH, Secularism in India: a Rejoinder . . . . 166

Revolution and the Rule of Law

Daniel S. Lev, The Politics of Judicial Development in Indonesia .

Arthur Taylor von Mehren, Comment on "The Politics of Judicial

Development in Indonesia" . . . . . . . . . 200

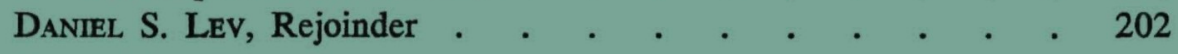

Social Mobility and the Legal Profession

GARY B. NASH, The Philadelphia Bench and Bar, 1800-1861 . . 203

\section{Nationalist Movements}

KonSTANTIN Symmons-SymoNolewicz, Nationalist Movements: an

Attempt at a Comparative Typology . . . . . . . 221

International Congress of Economic History, Munich (23-27 August

1965).

Editorial Office

Department of History, University of Michigan, Ann Arbor - Mich., USA.

\section{Subscription}

Comparative Studies in Society and History appears four times a year. Annual subscription $\$ 6.00$ (U.S.A.) or 23 Dutch guilders (or the equivalent in other currencies) payable through booksellers, through the Editorial Office, Department of History, University of Michigan, Ann Arbor, Michigan, or directly to the publisher: Mouton and Company, The Hague, The Netherlands. (N.B. Two years subscription rate $\$ 11.00$ or the equivalent, three years' subscription rate $\$ 15.00$ or the equivalent).

() Copyright 1964 by the Society for the Comparative Study of Society and History 